\title{
Overdosedødsfall - fra en klinikers hverdag
}

\author{
Ved Øivind Ekeberg
}

\section{Klassifikasjon}

Det kan ved første $\varnothing$ yekast virke selvsagt hva som menes med et overdosed $\varnothing$ dsfall. De fleste vil vel tenke at det dreier seg om et d $\varnothing$ dsfall som er en følge av en overdose av et giftig middel. Forgiftningsd $\varnothing$ dsfall dreier seg imidlertid om flere grupper, og disse gjennomgås nedenfor med ICD10-koder. Hvis ikke annet er nevnt, angis tall i henhold til Statistisk sentralbyrås dødsårsaksstabeller (1998).

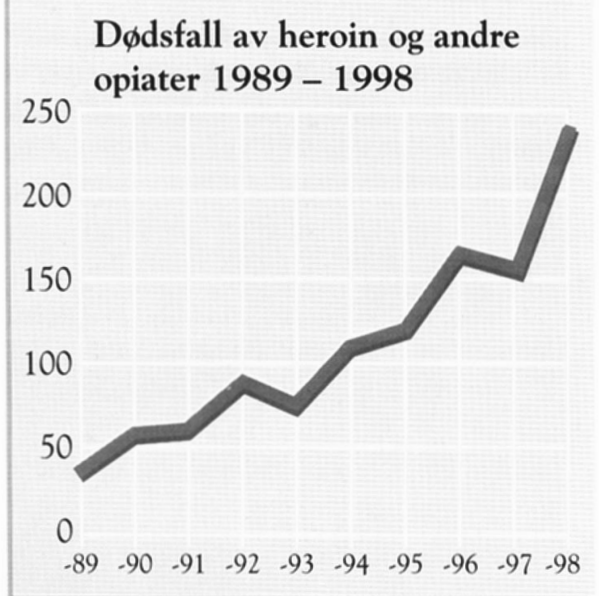

a) Dødsfall knyttet til awhengighet av stoff eller medikamenter (F11-F16, F18-F19)

Det er dette som vanligvis omtales som overdosed $\varnothing$ dsfall. De fleste av disse skyldes opioider (hovedsakelig heroin og morfin). Slike dødsfall vurderes ikke som selvmord. Hvis avd $\varnothing$ de hadde til hensikt å d $\varnothing$, skal det klassifiseres som selvmord. I tiårsperioden 1989-1998 var det en 7-dobling i antall dødsfall som skyldtes opioider. I 1998 var det 243 dødsfall, fordelt på 200 menn og 43 kvinner. Dødsratene var i 1998 høyest i aldersgruppene 25-34 år og 35-44 år med 16.2/100 000/år i begge grupper. Raten er nesten fem ganger høyere blant menn, og i gruppen 35-44 år var den for menn 27.7. Det er store geografiske forskjeller i overdosed $\varnothing$ dsfallene. $40 \%$ fant sted i Oslo og $15 \%$ i Akershus. Det har vært en $\varnothing \mathrm{kning}$ i gjennomsnittsalderen for opioidd $\varnothing \mathrm{d}$ sfall i de senere år, noe som først og fremst skyldes at mange misbrukere er blitt eldre. Det er relativt mange overdosedødsfall i Norge, også sammenlignet med land som har flere narkotikamisbrukere. Dette henger delvis sammen med høy forekomst av sprøytenarkomani i Norge. b) Alkoholbetingete psykoser/awhengighet av alkohol (F10)

I praksis dreier det seg om d $\varnothing$ dsfall knyttet til forgiftning med alkohol. I 1998 var det 176 slike dødsfall, 148 menn og 28 kvinner. Raten er høyest blant menn i aldersgruppen 65-74 år hvor den er 23.1. Det dreier seg altså om mennesker som har hatt et langvarig alkoholmisbruk bak seg. I denne kategorien regnes ikke andre $\mathrm{d} \varnothing \mathrm{d}$ sfall som følge av alkoholmisbruk. Dette antallet er ikke klart, men minst 1500 årlig er et vanlig estimat.

\section{c) Selumord som følge av forgiftning (X60-69)}

I 1998 var det 138 selvmord som følge av forgiftning, 86 menn og 52 kvinner. Når man trekker fra dem som døde som følge av eksosforgiftning fra bil, som nesten bare er menn, er kjønnsfordelingen ganske lik. Forgiftning utgjør altså $25 \%$ av alle selvmord.

\section{d) Forgiftningsulykker (X40-X49)}

Dette er forgiftningsd $\varnothing \mathrm{d}$ sfall av andre grunner. Det kan dreie seg om uhell med gasser, kjemikalier, medikamenter, sopp eller annet. I 1998 var det 66 dødsfall etter forgiftningsulykker, hvorav 49 menn og 17 kvinner.

e) Skade der det er ukjent om årsaken er et uhell eller er påført med hensikt (Y10-Y34, Y87.2)

I denne kategorien var det i 199813 dødsfall, hvorav 11 var menn. Dette er i hovedsak dødsfall som følge av forgiftning. Kategorien benyttes lite, og utgjør bare $2 \%$ av alle selvmord. I Sverige benyttes denne kategorien vesentlig mer enn i de fleste naboland.

\section{Avgrensninger}

Klassifikasjon i henhold til disse gruppene er forbundet med en viss usikkerhet. Avgrensningen mellom ulykke og selvmord er ofte vanskelig. Selvmordshandlinger uttrykker vanligvis ambivales, noe som også viser seg i handlingsm $\varnothing$ nsteret. Selvmordsmetoder som har st $\varnothing$ rre muligheter for overlevelse, anvendes oftere enn mer brå og dødelige metoder som skyting eller hengning. Ved forgiftninger er det muligheter for å ombestemme seg og bli reddet. Intensjonen ved inntak av medi- kamenter kan ha vært å dø, mens den kan være det motsatte når virkningen kommer.

Det er flere unders $\varnothing$ kelser som tyder på at omtrent $1 / 3$ av alle selvmord finner sted i alkoholpåvirket tilstand, og omtrent halvparten ved de selvpåførte forgiftningene. Bevisstheten kan altså være betydelig redusert, slik at intensjonen kan være vanskelig å vurdere. Det er sannsynlig at resultatet i mange tilfeller er bestemmende for hvordan man vurderer intensjonen. Dødsfall klassifiseres lett som selvmord, mens overlevelse lettere vurderes som rop om hjelp. Selvmordsintensjonen kan imidlertid undervurderes ved overdoser i alkoholpåvirket tilstand. Noen drikker for å få styrke til å gjennomføre et selvmord, mens andre kan gjøre det fordi de vet at alkohol $\varnothing$ ker sannsynligheten for å $\mathrm{d} \phi$.

Det hender også at appellpregete overdoser ender med døden. Vi har opplevd at pasienter har tatt tabletter som de trodde var ufarlige. Likevel medførte tablettinntaket at pasientene d $\varnothing$ de. Dette kan blant annet skyldes antakelser om at reseptfrie medikamenter ikke kan være dødelige.

Blant overdosed $\varnothing$ dsfallene kan det også være usikkerhet med hensyn til klassifikasjon. De fleste dødsfall som skyldes opioider, klassifiseres som ulykker. Unntaket er hvis det foreligger tegn på at det dreier seg om selvmord. Dette vil særlig være tilfellet hvis det foreligger avskjedsbrev eller andre meddelelser om at vedkommende $\varnothing$ nsket å $\mathrm{d} \varnothing$. Det er imidlertid ikke usannsynlig at noen narkomane tar sitt liv uten at de har kommunisert dette til andre. Når man snakker med langtkomne narkomane, sier de fleste at de har fors $\varnothing \mathrm{kt}$ å ta livet sitt en eller flere ganger tidligere. Dødsfallene klassifiseres også etter hvilke midler som er inntatt. Hovedmidlet klassifiseres først, og dette skal være det antatt farligste stoffet. Dette kan være vanskelig å vurdere fordi mange tar flere medikamenter samtidig, og kanskje alkohol i tillegg. Selv om trisykliske antidepressiva, paracetamol og salicylater i utgangspunktet er farligere enn nevroleptika og benzodiazepiner, er vurderingen av hva som er hovedmiddel ofte komplisert. Kombinasjoner av giftstoffene medfører $\varnothing \mathrm{kt}$ risiko. Ved et samtidig inntak av $250 \mathrm{mg}$ amitriptylin (Sarotex) og $2500 \mathrm{mg}$ chlorpromazin 
(Largactil) vil nok de fleste vurdere chlorpromazin som hovedmiddel. H vor mye mer amitriptylin må til før dette vurderes som hovedmidlet? H va er hovedmidlet etter inntak av $50 \mathrm{mg}$ diazepam og en alkoholkonsentrasjon på 0.5, 1.5 eller 2.5 promille? Et eller annet sted mellom de to ytterpunktene må alkohol vurderes som hovedmidlet.

A I kohol undervurderes ofte som hovedmiddel ved forgiftninger. I en undersøkelse av alle forgiftninger blant pasienter som ble innlagt i medisinske avdelinger i 0 slo i 1980, fant Jacobsen og medarbeidere (1984) at alkohol var vanligst både som hovedmiddel ( $20 \%$ ) og tilleggsmiddel $(35 \%)$. Her ble klassifikasjonen foretatt av en klinisk toksikolog, og dermed vektlegges al koholens betydning mer realistisk enn i mange andre studier.

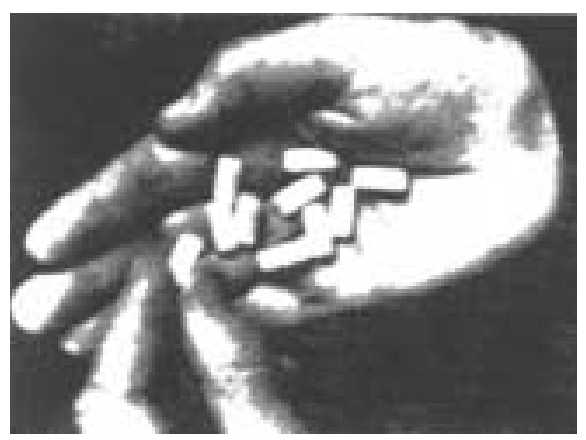

\section{Opioidrelaterte dødsfall hos stoffmisbrukere}

I en norsk undersøkelse ved Rettsmedisinsk institutt i 0 slo vurderte Filseth og medarbeidere (1991) obduksjonsfunn, omsten digh eter og rettstoksi kologi ske analyser av 86 stoffmisbrukere som døde i forbindelse med opiatinntak i perioden 1986-88. O mtrent en tredjedel hadde inntatt alkohol i tillegg til narkotiske stoffer.

Som følge av høy grad av tilvenning er det vanskelig å fastsette noen bestemt grense for hvilken konsentrasjon av opioid som er dødelig i hvert enkelt tilfelle. I dette materialet var det imidlertid $44 \%$ som hadde konsentrasjoner som lå i eller under det som regnes som terapeutisk. I flere tilfeller var dødsfallene en følge av injeksjon i sittende stilling hvor hodet hadde falt fremover og forårsaket kvelning. A ndre årsaker kan være inntak av andre medikamenter, alkohol, svekket fysisk tilstand og andre kroppslige sykdommer.
Blant de 86 døde var det to som hadde skrevet avskjedsbrev, og ytterligere ett tilfelle ble vurdert som selvmord. Disse tre hadde morfinkonsentrasjoner i blodet som lå 3-4 ganger høyere enn gjennomsnittet. U ndersøkelsen tyder på at de fleste opioidrelaterte dødsfall er en føl ge av ulykker. I noen få tilfeller (3-5\%) foreligger det sikre tegn på at det har vært selvmord. Det var disse som hadde de høyeste konsentrasjonene av opioider.

U ndersøkelsen er av noe eldre dato. $\mathrm{N}$ oen av hovedkonklusjonene er trolig holdbare fortsatt, men det er behov for nye under-søkelser av forgiftningsdødsfall etter at omfanget av slike dødsfall har $ø k t$ og misbruksmønsteret har endret seg.

\section{Kliniske aspekter ved selvpåførte forgiftninger}

Selvpåførte forgiftninger som fører til innleggelse i en medisinsk avdeling eller som blir behandlet ved legevakt, dreier seg om en blanding av selvmordsforsøk, rop om hjelp eller som følge av utilsiktede forgiftninger. Erfaringene fra U Ilevål sykehus er at omtrent ca. $20 \%$ av tilfellene vurderes som selvmordsforsøk, ca. $60 \%$ som appellreaksjoner eller rop om hjelp og ca. $20 \%$ som ulykker. I omtrent halvparten av tilfellene som vurderes som rop om hjelp, oppgir pasientene i første omgang at de har gjort et selvmordsforsøk. $\mathrm{N}$ år dette ikke blir klinikerens vurdering, er det fordi sannsynligheten for å overleve ble vurdert som for stor. I slike tilfeller har gjerne pasientene ringt etter hjelp kort tid etter inntak av de giftige stoffene, det var kanskje andre til stede som kunne sikre behandling, eller inntaket var så begrenset at vedkommen de måtte forstå at det ikke kunne være dødelig. Blant ulykkestilfellene er de fleste knyttet til rusatferd, hvor virkningen har vært sterkere enn antatt. Tidligere var dette i hovedsak forgiftninger med opioider. $\mathrm{N}$ å kommer det i økende omfang forgiftninger også med rusmidler som benyttes i de nyere rusmiljøene, slik som $\mathrm{GH} B$, ecstasy, kokain og amfetamin.

Den somatiske behandling av akutte forgiftninger er nå så god at dødeligheten blant innlagte pasienter er mindre en n $1 \%$. De fleste som dør, har allerede ved innleggelsen hatt betydelige komplikasjoner som respirasjonsstans eller sirkulasjons- stans. Svarende til dette finner de fleste overdosedødsfall sted utenfor sykehus.

Etter behandling av den akutte forgiftningen har praksis ved U Ilevål sykehus de siste 20 årene vært at alle pasienter får tilbud om å snakke med psykiater eller sosionom. H ensikten er å kartlegge helseproblemene, iverksette kriseintervensjon og å sikre adekvat oppføl ging etter utskrivning.

H ovedproblemene varierer betydelig. 0 ftest dreier det seg om psykiatriske lidelser i kombinasjon med relasjonsproblemer, rusproblemer, yrkesmessige eller sosiale problemer. De fleste har også tidligere hatt betydelige bel astninger. Psykiatriske lidelser har generelt lavere status både i den generelle befolkning og blant behandlere, og dette gjel der i en da høyere grad misbrukere. Som kliniker er det derfor en oppgave å være en talsmann for pasientene både i somatiske avdelinger, overfor psykiatriske avdelinger, avdelinger for behandling av misbrukere og overfor ansvarlige myndigheter.

Det er beklagelig at det er blitt så vanskelig å få plass i psykiatriske akuttavdelinger. $M$ ange pasienter som sliter med psykiske problemer og ensomhet, har behov for mer støtte og omsorg i tiden etter et selvmordsforsøk enn de kan få ved poliklinisk oppfølging. I tillegg kan det gå flere uker før de får time, og oppfølgingen blir i mange tilfeller for kortvarig.

$M$ ange misbrukere kommer i en vanskelig mellomposisjon mellom psykiatrien og rusmiddelomsorgen. Vi har sett flere eksempler på at pasienter har tatt livet sitt som følge av dette. Det har oftest vært knyttet til at hovedproblemene er blitt omdefinert fra depresjon til rusproblemer, med overføring fra psykiatrisk avdeling til et A -senter.

$O$ gså når rusmisbruk er hovedproblemet, kan det være vanskelig. Flere av A -sentrene tar først inn pasientene etter en eller flere polikliniske forhåndssamtaler. $\mathrm{Vi}$ har gjentatte ganger gitt misbrukere mye akuttmedisinsk behandling inklusive avrusning. $\mathrm{N}$ år pasientene har en realistisk vurdering av at de kommer til å drikke igjen hvis de blir utskrevet til hjemmet, er det beklagelig at de ikke kan oppnå en direkte overføring til et A -senter når de er motivert for dette. 


\section{Forløpet etter selvpåført forgiftning}

I Jacobsen og medarbeideres materiale (1984) var det 952 personer som stod for 1145 innleggelser i løpet av 1980. H alvparten var kvinner, median alder 32 år, og $17 \%$ ble vurdert som alvorlige selvmordsforsøk. Blant dem som ikke var misbrukere, ble $25 \%$ vurdert som alvorlige selvmordsforsøk, blant alkoholmisbrukerne $10 \%$ og blant opiatmisbrukerne $2 \%$. O mtrent halvparten av pasientene var misbrukere, $63 \%$ av mennene og 36 $\%$ av kvinnene. Det var $25 \%$ som misbrukte alkohol, $12 \%$ opioider og $11 \%$ andre midler.

De 926 personene som ikke var utlendinger eller som hadde emigrert, ble undersøkt etter 10 år (Ekeberg et al. 1994). Det var $22 \%$ av pasientene som var døde ved oppfølging, $28 \%$ av mennene og $17 \%$ av kvinnene. Dødeligheten var markert høyere blant misbrukerne, høyest blant misbrukere av opioider ( $33 \%$ ) og alkohol (28\%), mens den blant ikke-misbrukerne var $15 \%$. O gså blant ikke-misbrukerne var det en kjønnsforskjell, i det $20 \%$ av mennene og 13 $\%$ av kvinnene var døde. Det var like mange selvmord blant kvinner og menn slik at blant dem som døde, var dødsårsaken selvmord hos $29 \%$ av kvinnene og $16 \%$ av mennene.

\section{Dodsrate (/1000 pr. âr)}

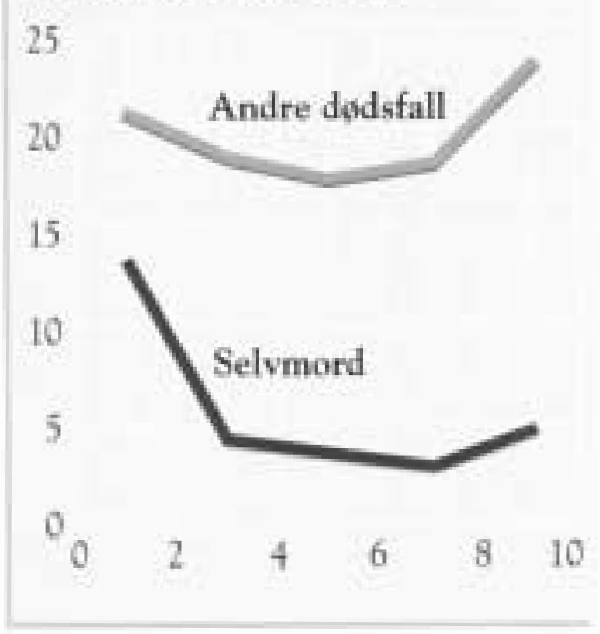

Å rlig dødsrate ( selvmord og andre dødsårsaker) i oppfølgingsintervallet ( 0 - 10 år)

( $95 \%$ konfidensintervall er oppgitt)
Ved en logistisk regresjonsanalyse kom det frem at misbruk, høyere alder, og at det var en mann, ga selvstendige bidrag til å forklare risiko for død. Den eneste faktor som ga en uavhengig forklaring på risiko for selvmord, var at overdosen klinisk ble vurdert som alvorlig selvmordsforsøk.

Den alvorlige prognosen blant misbrukere kommer enda tydeligere frem når man ser på aldersgruppen under 30 år (Ekeberg et al. 1999). Femten år etter innleggel sen var $43 \%$ av de mannlige og $23 \%$ av de kvinnelige misbrukerne døde. Blant dem som ikke var misbrukere, døde $16 \%$ av de unge mennene og $6 \%$ av kvinnene.

\section{Sammenfatning}

Den høye dødeligheten som følge av overdoser er både knyttet til rusmisbruk, selvmordsatferd og de psykososiale problemene som disponerer for dette. Den begrensete kapasiteten innen psykiatri og rusmiddel omsorg gjenspeiler den lavere status mennesker med slike problemer har. Dette er en utfordring for alle som arbeider i dette feltet.

\section{Konklusjon}

- O verdosedødsfall dreier seg oftest om dødsfall som følge av ulykker knyttet til inntak av opioider.

- Det er et betydelig antall dødsfall som følge av forgiftninger med alkohol.

- Den tredje store gruppen med dødsfall som følge av forgiftninger er selvmord.

- Dødeligheten etter selvpåført forgiftning er så høy at en slik handling må betraktes med samme alvor som en malign tilstand.

- Risikoen for død etter selvpåført forgiftning er spesielt høy blant misbrukere, blant eldre og blant menn.

- Dødelighet som følge av misbruk har vært undervurdert i forbindelse med selvpåførte forgiftninger.

- En klinisk vurdering av at en selvpåført forgiftning er et al vorlig selvmordsforsøk utgjør en meget viktig risikofaktor for senere selvmord.

\section{Referanser}

D ødsårsaker 1998. Statistisk sentral byrå 2001, www.ssb.no/dodsarsak/

Ekeberg $\varnothing$, Jacobsen $D$, Ellingsen $\varnothing$. M ortality and causes of death in a 10-year follow-up of patients treated for self-poisonings in 0 slo - a research note. Suicide Life Threat Behav 1994; 24: 398-405.

Ekeberg $\varnothing$, Knutsen BA, Jacobsen D. A 15 years follow up study of self poisoning among patients under $\mathbf{3 0}$ years in $\mathbf{0}$ slo. A bstract presented at the $X X$ C ongress of the International A ssociation for Suicide Prevention. A thens, G reece 1999.

Filseth $O M$, Fossen $K, H$ alvorsen $V B, H$ jelle $D$, $\varnothing$ stheim $E$, Sortebogen $M$, Teige $B$, Ekeberg $\varnothing$. O piatrelaterte dødsfall hos stoffmisbrukere (19861988). Tidsskr N or Lægeforen 1991; 111: 1629-32.

Jacobsen D, Frederichsen PS, K nutsen KM, Sørum $Y, T$ alseth $T, \varnothing$ degaard O R. A prospective study of 1212 cases of acute poisoning.

G eneral Epidemiology. H uman Toxicology 1984; 3: $93-106$.

Oivind Ekeberg er onerlege i polkiarti red Akuttmedisinik and., Ulleval universitets. whehus, og professor i medisincke atfendsfas ved Univenuteret i Ola

Artikler om rus som har statt i tidligere nr. av Suicidologi:

Carr, Nicholas

"Dobbelt utsatt" $\mathrm{r}$ refleksjoner omkring selvmord, stoffmisbruk og psykiske lidelser.

Suicidologi $2001: 6(1): 20-21$

\section{Retterstal, Nita}

Rusmiddelbruk og selvanord. Suicidologi $19999 ; 4(1): 16-17,20$

Rossow, Ingebort

Alkohol og selvmord.

Nyrr t suicidologi 1997; 2 (1): 12-14

\section{Andre referanser:}

Murphy, Georg E

Suicide in alcoholism.

New York: Oxford University Press, 1992

\section{Retterstod, Nils}

Alkoholmisbruk og selvmond. 1 Riise, G et al Al Alkohol og helse - det bagatelliserte alwor. Oslot Universitetsforlaget, 1995 : 159.63 